\title{
THE EFFECT OF GOVERNMENT POLICY ON HOUSING DELIVERY IN NIGERIA: A CASE STUDY OF PORT HARCOURT LOW INCOME HOUSING PROGRAMME
}

\author{
${ }^{1}$ John Owuike Iheme, ${ }^{2}$ James Bassey Effiong, ${ }^{3}$ Samuel Bassey Ekung \\ ${ }^{1}$ School of the Built Environment, University of Salford, United Kingdom. \\ ${ }^{2}$ Department of Estate Management, Cross River University of Technology, Calabar. \\ ${ }^{3}$ Department of Quantity Surveying, Imo State University, Owerri. \\ Email address: jamesbassey4real@yahoo.com, Tel: 07032544821
}

Keywords: Affordability, delivery, effect, government, housing, low income.

\begin{abstract}
Housing is one of the most important needs of individuals next to food and clothing. Housing needs for low income earners has reached an alarming stage in Nigeria. On the supply side, numerous government policies have earlier aimed at disabling the massive shortage through numerous housing reform programmes. Despite these preceding efforts, housing remains an illusion to an average Nigerian. This research assessed the effect of government policy on housing delivery in Nigeria. The objectives were to determine housing needs of the low income group in Nigeria and to determine the impact of government policies on affordable housing provision to the low income group. Survey method was used to collect data from 44 respondents through the administration of questionnaires which was analyzed with statistical tools. The findings from the study shows that insufficient fund is closely related to other finance related factors identified as barriers to the accessibility of public housing by the low income group who are non-public servants. Such factors as high interest rate, low per capita income, lack of security of income, lack of collateral and high cost of public houses. The study suggest the creation of a viable secondary mortgage market, improvement of land registration and allocation, compassionate urban renewal programmes, cost saving house designs amongst others.
\end{abstract}

\section{INTRODUCTION}

Housing means more than just a shelter; it is to be understood in the context of one's immediate living environment, comprising the shelter itself and its surroundings. Besides providing protection from the elements of climate, housing provides privacy for relaxation and facilities, full development of family life etc. Housing signifies one of the most rudimentary human needs. As a unit of the environment, it has a reflective influence on the health efficiency, social behaviour, gratification and general welfare of the community (Onibokun, 1998). It is thus defined as buildings or other shelters in which people live, a dwelling and to a Nation, critical component in social and economic strata (Kabir and Bustani, 2010). Good housing is very necessary to welfare, survival and health of individuals. A study by UN (1996) reported in Aribigbola (2011) expressed growing concern over the deteriorating housing conditions in urban areas of developing nations. Based on these growing concerns, and to meet the numerous housing challenges especially in developing countries, the International community established the Habitat Agenda on housing in Istanbul to provide shelter for all, achieve sustainable human settlements as well as the recognition of primary responsibility for implementing the Habitat Agenda (Aribigbola, 2011).

In recent time, housing needs for low income earners has become a common way of summarizing the nature of housing problems globally. The gross mismatch between housing demand and housing supply in urban areas, especially in the developing countries of the world, tends to be the dominant issue in discussions of urban housing problems. In Nigeria, the growing level of industrial and commercial activities in the urban centres has contributed to continuous drift in shortage of residential accommodation, as the existing supply of housing could not match the 
increasing level of demand. The rate of homelessness and high cost of rent is also alarming. Most urban residents in Nigeria today are living in decrepit houses lacking basic amenities, poor sanitary conditions or running water, most urban areas are the worst for wear as far as infrastructure and housing are concerned, and this commonly is due to disreputable poor maintenance culture. Continuous efforts to meet every set target have failed as housing insufficiency now stands at above 16 million units in Nigeria (Peterside, 2003).

Government's drive toward housing for all as contained in the National Housing Policy, which aims to provide affordable housing for all, has so far not been achieved and no serious efforts are being made toward implementation as it continues to be an illusion and frustration to the larger population (Adejumo, 2008). The failure has been partly attributed to the lack of political will and poor implementation (Adejumo, 2008). From time to time, government often make continuous discrete policy and programme to address housing problems in Nigeria, but there seems to be no review mechanism that reports on the performance of these policies. Such review may necessitate re-appraisal for continuous improvement and lessons learned transferred to other areas. Port Harcourt is an important commercial centre in the Niger Delta area of Nigeria. Its strategic location in this region of Nigeria led to its population growth primarily through immigration from the surrounding rural areas. The rapid urbanization and industrialization growth in Port Harcourt results in shortage of housing and other related problems including associated infrastructure. This is recognized in both qualitative and quantitative terms as shortage of low income housing for low income group. The rising cost of available units made it increasingly difficult for low income households to maintain an acceptable standard of living in Port Harcourt fuelled by the lack of effective government policy to successfully drive the Nigerian housing sector. This study therefore, seeks to investigate the effect of government policy on the provision of housing for the low income earners in Port Harcourt.

\section{REVIEW OF RELATED LITERATURE} Overview of housing affordability problem

Housing affordability is defined as the capacity in making households meet their periodic mortgage needs without jeopardizing their health or reducing other basic family need (Agbola 2005). Housing is the conglomerate of shelter plus environment which includes the housing unit, site layout and the facilities within the environment. However, in 2005, the United Nations said that the inhabitants of Nigeria was 141 million, and projected its growth toward the region of 289 million by 2050. A similar projection was also witnessed when the United States Census Department predicted that the population of Nigeria will increase by 264 million by 2050 . If these predictions come true then Nigeria will become the $8^{\text {th }}$ most populous nation globally (Encarta, 2007) as cited in Kabir and Bustani (2010). This continued increase in population is creating a burden to shelter and effective supply and delivery of simple amenities and facilities for all urban residents. In most cities, the observed problem with housing distribution is not only reduced to quantity but also to the poor and the quality of available housing units (Kabir and Bustani, 2010). This problem is also seen in overcrowding in many available houses mostly occupied by the poor. Urbanization has also led to increase on the demand in housing provision and is one of the major challenges facing Nigeria's lack of affordable housing.

A major problem working against sustainability in housing and urban improvement in most developing nations is that of unrestrained spread (Jiboye, 2011). It has also existed that urban expansion and weak economic progress have heightened the difficulties of low income accommodation in Nigeria. These housing shortages, especially aimed at the poor has increased because of population growth, inflation in real estate prices, rural- urban migration, reduced municipal services and structures plus weak implementation of public housing guidelines and programmes. Other factors may include household size, educational background, occupation, stage of family life cycle, access to source of institutionalized housing finance and culture. Housing needs for the low income earners is in high demand as a result of population growth and rapid urbanization due to rural urban relocation, increased rate of building supplies and unsuccessful 
housing policy. Nigeria's effort to housing for all as enclosed in the National Housing Policy of 2002, which objective is to provide affordable housing have so far being mere rhetoric. Small salary earners mostly do not have enough for food, clothing, transportation and other family needs, thus because of these needs, it is impossible to save and buy or build a house because of financial restraint. Most of the low income earners hardly have bank account; hence are not even eligible for bank loans or mortgages. In most cases, they are not qualified for employer's loans because their income is too low to meet the repayment obligations.

A recent study based on the salary structure of public servants in Nigeria showed that no public servant in Nigeria below salary grade level 13 in the Federal Civil Service can afford a property costing N4.5 million on a 25 years mortgage at $6 \%$ even if they devote $50 \%$ of their salaries per annum to housing (Onyike, 2009). At about 18\% mortgage rate, only a Federal Permanent Secretary or his equivalent on grade level 17 can afford the same type of house. This proves that, in the lack of some support, sufficient housing will be too expensive to most Nigerians especially the low income earners. A new study of housing position in Nigeria places obtainable standard at 23 per 1,000 inhabitants and housing shortage is set at 15 million houses while N12 trillion will be required to back the deficit (Mabogunje, 2002). This is roughly four times the yearly domestic financial plan of Nigeria (FHA, 2007). The national rolling plan of $1990-1992$ assessed housing deficits to 4.8 million. The 1991 housing program projected that 700,000 housing units stand to be built every year if housing shortage is to be canceled. In 2006, the ministry of Housing and Urban Development stated that Nigeria needed about 10 million housing units before all Nigerians can be sheltered. In the middle of 1975 and 1980, there were strategies to supply 202,000 housing units to the public but only 28,500 units representing $14.1 \%$ was achieved. In the National Housing Fund (NHF) programme initiated in 1994, which aim was to create 121,000 housing units, less than 5\% was also realized. In spite of succession of government policies toward housing delivery, an obvious fact is that there still remains a huge breach concerning housing quantity and request (Olomolaiye 1999) as cited in Kabir and Bustani (2009).

\section{CONCEPT OF HOUSING AFFORDABILITY}

Agbola (2005) have noted that for housing to be affordable for the low income earners, it must be tailored to total income level. Inexpensive housing is used to define dwelling units whose total housing budgets are considered reasonable to a group of people in a definite salary scale. However, the governmental agency of 2002 on housing and inner-city development, defines low income earners as all employee or entrepreneurs whose yearly revenue in 2001 is N100,000 or below (with $\mathrm{N} 260=£ 1$ ). When the monthly budget of a home surpasses $30-35 \%$ of family wages, then the housing is measured excessive for that family. The United States Department of Housing and Urban Development (HUD) policy makers specified that for housing system to be reasonably priced, the family should not pay other than $30 \%$ of its full income on rent payment and services, where they possess their own home, not higher than $30 \%$ on their mortgages, insurance, taxes and utilities. Housing becomes affordable only if it meets this 30\% test (Adediji, 2006). A review of city housing in Nigeria points out that rental fee accounts for about $60 \%$ of the income of an ordinary worker with the remaining $40 \%$ for food, clothing, health, transportation and other requirements; a percentage that tosses the wage earner into extreme insufficiency. This completely ignores the United Nations description of inexpensive housing. Affordability is hence the fundamental of any societal housing scheme. If the system is not low-cost, then it is not justifiable.

Adedeji (2006) stated that a household survey in Nigeria indicates that accommodation takes a generous portion of a salary earner and has remained a standard for judging any regime's performance in the socio-economic and political spheres of a country. The private sector understands housing from a broad viewpoint than the public sector, because humans are measured by the kind of houses they live in and its location. This means that the category of house one occupies is a measure of his/her personality and economic worth in the society. In Nigeria, the drive toward achieving the housing for all is continuously becoming an illusion due to the size of the population. With about 200 million in population and an estimate of housing need of over 1 million 
and is always rising as the day goes by, this has become a hard task. Greatest number of city residents in Nigeria lives in shanty-towns and derelict homes short of simple conveniences, unhygienic surroundings and water. By the emergence of a different National Housing plan and the resurgence of numerous primary mortgage institutions (PMIs) in the last 15 years, either as independent or as businesses of depositary organizations coupled with an aggressive operation of the private developers, the housing needs are far from being realized (Nubi, 2000).

Mutually, Federal and State governments and even agencies have experimented into low cost housing schemes for workers with some degree of success. The truth is that a mortgage lending system as known in Nigeria is based on short term loans even in rising inflation and high interest frequency. This is grossly inadequate and cannot produce affordable housing requirement in Nigeria. The current operations of private developers in Nigeria have brought some marginal increase in the housing stock but these are far from being affordable. Nigerian housing need is swayed by the urban general population growth of 5\%. In the 1990s, a yearly urban condition for housing units was 400,000 units and there is a huge need for improvement and extra units of existing housing stock. As at 2005, an annual report estimate shows that more than 1.4 million housing is required (Adediji, 2006). But, currently it is estimated to be in the region of about 2 million (NHA, 2012). Recently, the Federal Government established and commenced the implementation of National building codes and criteria, also a National Building Policy was broadcasted in 1994 to certify and enhance the construction division to meet human resettlement expansion goals and to avoid damaging side effects on human well-being. That was the scheme which emphasized the use of local building materials and industries criteria. All these efforts notwithstanding, it was revealed by UN-HABITAT (2002) that most Nigerians rely on assistance from friends in order to build their houses. This is due to the fact that government has not played any successful role in housing delivery.

\section{QUALITATIVE HOUSING SHORTAGE}

The short supply of housing stock for the low income earners in Port Harcourt is a global phenomenon subduing developing countries. Habitat (1990) noted that in all countries, regardless of the average standard of short supply of housing stock, most of the low income earners now resort to live in accommodations which is more substandard, street sleeping, slums and water front. Low income earners in Port Harcourt live in ramshackle houses with absence of simple facilities, unhygienic environments and running water. World Bank (1993) states that majority of poor quality structures are built in informal settlements and overcrowded dwellings where house-holds occupy a small space or share a dwelling with others. Interest tariffs in Nigeria are very high, if the rates go to as high as $10 \%$ in most of the advanced nations, there will be an excess supply in the housing market as fewer people will be unprepared to purchase at such a high amount of interest on loan. The recent global economic down turn has forced mortgage rates down to as low as 3\% in some countries, especially the UK and USA. But the case of Nigeria is different with interest rate getting as high as 18 to 22 percent. Alao (2009) noted that it is absolutely difficult for a low-income earner to service any loan at such high interest rate. The long term absence of mortgage banks as seen in the developed nations like UK can be responsible for this occurrence. Even with the creation of primary mortgage institutions, the banks are still unable to lend at low interest rates. Factors such as high cost of building materials and cost of land has being seen to be responsible for the shortage in qualitative housing.

\section{CRITICAL REVIEW OF GOVERNMENT POLICY ON PROVISION OF LOW INCOME HOUSING \\ National Housing Policy (1991)}

This policy intends to solve the problems of Nigeria's housing needs. Its main aim includes land and settlement development policy, housing finance, building material and construction cost, low income housing, and monitoring and evaluation. This policy also provide that government should hands off direct construction of housing units for civil servants but rather encourage them 
through enabling policy mandate to own their own houses. The National Housing Policy documents has some bold steps towards facing shelter challenges but lack implementation strategies strictly in accordance with local and economical situations. Like the previous housing policies, the current National Housing Policy may not attain its goal for housing for all. This is due to the fact that the National Housing Fund which is expected to disburse funds is not yet committed to its primary assignment which is making funds available for onward lending to the public for development. The Nigerian housing situation and its policies in housing provision could be said to be in a crises which began from how badly the policies are performing, the escalation of the problems and the government's lack of interest, carelessness and implementation of making good policies and promises which is capable of improving housing delivery. The policies and programmes of government on ground are not people oriented to achieving affordability in housing as they are also unattractive to developers. They are government oriented policies in the sense that it benefits the government more through taxation and compulsory acquisition than the people it was meant to improve their living standard. For instance, while researching the housing policies, we could not find any National Policy on planning which promotes affordable housing such as Planning Obligation which has been proven to be one of the developmental catalysts with the ability to improving low income housing need of any nation. This policy has helped most countries who adopted it especially the United Kingdom (Basingstoke and Deane, 2012).

\section{Effect of Government Policy on Housing Delivery}

The Nigerian National Housing plan which was launched in 1991 in reaction to the Agenda 21 of global housing was expected to realize sustainable human settlement and development. The country's housing development policies are intended in courtesy of those in the middle and higher income groups, projected housing development for the poor are either hijacked, or not adequate. About $90 \%$ of housing construction is chiefly in the influences of individual reserved market. Land purchase up till now has been a major stumbling block to potential landlords, predominantly the low-income group. This was seen as a workable substitute to direct construction and production of houses by government in view of the putting into practice the Federal Low Cost Housing Scheme. The idea of site-and-service as a means of human settlements development dates from colonial times whereby government had adopted the methods of obtaining huge tracks of land, setting out and providing the vital infrastructure before allotting the serviced plots to persons or cooperate organizations development. Several parts of Nigeria's cities were urbanized in this manner (Daramola et al, 2009). Nevertheless, it is a point that the housing problem is far from being resolved; this can be credited to errors in the policies adopted by the government (Olayiwola, 2005).

\section{METHODOLOGY}

Descriptive and inferential research involving field survey was considered appropriate for the study. Data were collected using structured questionnaire and analysed using relevant statistical tools. A five point likert scale was used in ranking the respondent's responses and the judgement sampling was considered most appropriate based on the nature of the study. Purposive or judgement sampling technique which is a non-probabilistic sampling technique was employed in the selection of 70 (Seventy) respondents for the study drawn from the public and private sector, real estate professionals and stakeholders in housing development in Port Harcourt. The study attained 62\% response rate and is thereby adjudged sufficient for this study. Data for the study were processed and analysed with the aid of Statistical Packages for Social Science (SPSS). Data collected from the questionnaires distributed to respondents were analysed using statistical tools. The required test involved the determination of percentile score, mean score and standard deviation. Respondents characteristics and participants background were also analysed using percentages. 


\section{RESULTS AND DISCUSSION}

\section{Response to Questionnaire Administered}

The main research instrument used for the study is structured questionnaire. The instrument was administered on the population of the study. The response of the population to the research instrument was analysed. The results are presented in Table 1.

\section{Table 1: Response to the Study Questionnaires}

\begin{tabular}{lcc}
\hline Category of Respondents & Number & Percentile \\
Corporate Real Estate Professionals & 18 & 41 \\
Other Professionals in Real Estate Practice & 14 & 32 \\
Others & 12 & 37 \\
Total & $\mathbf{4 4}$ & $\mathbf{1 0 0}$ \\
\hline
\end{tabular}

A total of 70 questionnaires were administered to the different category of respondents. As shown in Table 1, 52 questionnaires were retrieved but 44 were fit for analysis. Others were disqualified mainly due to incomplete attempts notably on the key objectives of the study. The study therefore attained $62 \%$ response rate and is thereby adjudged sufficient for the study. Previous studies Ojo (2004) had adjudged response rate of $40 \%$ and above suitable to validate the findings of a study.

\section{Characteristics of Respondents}

The characteristics of the study population were analysed to ascertain respondent's suitability to provide opinion on the subject of the study. This is aimed at providing basis for the validity of the study data. For this purpose therefore six features were examined namely: gender; age; academic qualification; income class; information about property ownership and the condition of the property in which they owned. The result is presented in Table 2.

Table 2: Descriptive Statistics of Respondent's Characteristics

\begin{tabular}{|c|c|c|c|c|c|}
\hline \multicolumn{3}{|l|}{ Gender } & \multicolumn{3}{|c|}{ Income Class } \\
\hline Category & $\mathbf{N}$ & Percentile & Category & $\mathbf{N}$ & Percentile \\
\hline Male & 36 & 82 & Low & 12 & 27 \\
\hline Female & 8 & 18 & Middle & 22 & 46 \\
\hline Total & 44 & 100 & High & 12 & 27 \\
\hline Age & & & Total & 44 & 100 \\
\hline Category & $\mathbf{N}$ & Percentile & \multicolumn{3}{|c|}{ Ownership of Property } \\
\hline $18-30$ years & 8 & 18 & Response & $\mathbf{N}$ & Percentile \\
\hline $31-40$ years & 18 & 41 & Yes & 24 & 55 \\
\hline $41-50$ years & 14 & 32 & No & 20 & 45 \\
\hline $51-60$ years & 4 & 9 & Total & 44 & 100 \\
\hline Above 60 years & 0 & 0 & \multicolumn{3}{|c|}{ Residence Condition } \\
\hline Total & 44 & 100 & Response & $\mathbf{N}$ & Percentile \\
\hline \multicolumn{3}{|c|}{ Academic Qualifications } & Good & 23 & 52 \\
\hline Category & $\mathbf{N}$ & Percentile & Fair & 19 & 43 \\
\hline OND & 4 & 9 & Poor & 1 & 5 \\
\hline HND & 14 & 32 & Total & 44 & 100 \\
\hline BSc/B.Tech & 16 & 36 & & & \\
\hline MSc & 8 & 18 & & & \\
\hline $\mathrm{PhD}$ & 2 & 5 & & & \\
\hline Total & 44 & 100 & & & \\
\hline
\end{tabular}

$\mathrm{N}=$ Number of Respondents

Construction and the real estate sector has been mainly male dominant as evidence in the study's gender distribution. $82 \%$ of the study population is male while $18 \%$ are female. The age on the other hand is synonymous with the experience and relevant technical expertise in real estate 
practice, $41 \%$ are between 31 and 40 years; 32\% above 40 years, 18\% are between 18 to 30 years while $9 \%$ are above 60 years. Academic qualification shows that $68 \%$ have Higher National Diploma and its first degree equivalent, $23 \%$ have academic qualification above the benchmark of Masters of Science and Ph.D.

The income class indicates that $63 \%$ are middle and high class income earners while $27 \%$ are low income earners. $55 \%$ on the other hand owned the property in which they live while $45 \%$ are in rented or alternative accommodation. The overall condition of residence where the respondents live is good as shown by $52 \%$ of the respondents while $43 \%$ are in fair condition. Only a member of the study population acknowledge has condition that is bad and this represents an insignificant portion of the entire population.

\section{Why Previous Housing Schemes for the Low Income Failed}

This study's objective seeks to identify factors responsible for the failure of previous endeavour of the public sector to provide affordable houses for the low income group in the area. Qualitative data were collected utilizing ten factors identified from related literature survey. Respondents were asked to rank using 5 -point Likert Scale: $1=$ Very low; $2=$ low; $3=$ moderate; $4=$ High; and $5=$ Very High. The result is presented in Table 4.3

Table 3: Imminent Causes of Failure in Previous Low Income Housing Schemes

\begin{tabular}{|c|c|c|c|c|c|c|}
\hline Causes & Very Low & Low & Moderate & High & Very high & Total \\
\hline $\begin{array}{l}\text { Security of } \\
\text { tenure }\end{array}$ & $23 \%$ & $27 \%$ & $18 \%$ & $18 \%$ & $14 \%$ & 100 \\
\hline $\begin{array}{l}\text { Lack of } \\
\text { affordability }\end{array}$ & $0 \%$ & $9 \%$ & $4 \%$ & $23 \%$ & $64 \%$ & 100 \\
\hline $\begin{array}{l}\text { Poor } \\
\text { habitability }\end{array}$ & $0 \%$ & $0 \%$ & $14 \%$ & $41 \%$ & $45 \%$ & 100 \\
\hline $\begin{array}{l}\text { Lack of } \\
\text { services }\end{array}$ & $2 \% \%$ & $4 \%$ & $41 \%$ & $5 \%$ & $48 \%$ & 100 \\
\hline $\begin{array}{l}\text { Lack of } \\
\text { infrastructure }\end{array}$ & $9 \%$ & $0 \%$ & $23 \%$ & $32 \%$ & $36 \%$ & 100 \\
\hline Location & $24 \%$ & $5 \%$ & $19 \%$ & $22 \%$ & $24 \%$ & 100 \\
\hline $\begin{array}{l}\text { Lack of } \\
\text { cultural } \\
\text { compatibility }\end{array}$ & $0 \%$ & $4 \%$ & $14 \%$ & $27 \%$ & $55 \%$ & 100 \\
\hline $\begin{array}{l}\text { Inadequate } \\
\text { supervision }\end{array}$ & $26 \%$ & $18 \%$ & $22 \%$ & $15 \%$ & $19 \%$ & 100 \\
\hline $\begin{array}{l}\text { Inadequate } \\
\text { planning }\end{array}$ & $9 \%$ & $9 \%$ & $18 \%$ & $41 \%$ & $23 \%$ & 100 \\
\hline
\end{tabular}

Security of tenure as one of the causes of failure of previous low income housing scheme. The above result shows that security of tenure for land is low represented by $27 \%$, very low by $23 \%$, $18 \%$ for high and moderate and $14 \%$ for very high. In terms of affordability $0 \%$ went very low, $9 \%$ low, $4 \%$ moderate, $23 \%$ high and $64 \%$ very high. This indicates that housing affordability was high. For poor habitability, Low and very low were $0 \%, 14 \%$ moderate, $41 \%$ high and $45 \%$ very high indicating that habitability as cause of failure of past policies is very high. Lack of services show $4 \%$ for low, $2 \%$ for very low, $41 \%$ for moderate, $5 \%$ for high and $48 \%$ for very high. This result indicates that lack of services was very high. For lack of infrastructure, $0 \%$ went for low, $9 \%$ very low, 23\% moderate, 32\% high and 36\% very high showing that lack of infrastructure as cause of failure of low income housing is very high. Location of the houses show $5 \%$ to be low, $24 \%$ very low and very high, $19 \%$ moderate and $22 \%$ high. This means that location as a factor is very low. For cultural compatibility, 55\% answered very high, 27\% high, 14\% moderate, 4\% low and 0\% very low respectively. Inadequate supervision shows $26 \%$ for very low, $18 \%$ low, $22 \%$ moderate, 
$15 \%$ high and 19\% very high. For inadequate planning, 9\% represents low and very low, 18\% moderate, $41 \%$ high and $23 \%$ very high indicating a high rate of inadequate planning.

\section{Challenges Facing the Provision of Housing for the Low Income Group}

Extant deficits in housing stock for the low income group may not be entirely neglected. As seen from the foregoing literature review, there have been several attempts and policies aimed at meeting the housing needs of the low income group in Rivers State. This section of the study examined why the relevant government policies have not made significant impact as planned. Ten factors were identified: population growth; cultural diversities; lack of up-to-date about the low income group; lack of fund; lack of collateral, unemployment, ineffective legal and regulatory framework, land tenure system, non-involvement of the local stakeholders and difficult terrain. The perception of the respondents is presented in Table 4.

Table 4: Challenges Faced in Housing the Low Income.

\begin{tabular}{|l|l|l|l|l|l|l|}
\hline Challenges & Very Low & Low & Moderate & High & Very high & Total \\
\hline Population Growth & $9 \%$ & $2 \%$ & $14 \%$ & $41 \%$ & $34 \%$ & 100 \\
\hline Cultural diversity & $9 \%$ & $12 \%$ & $25 \%$ & $11 \%$ & $43 \%$ & 100 \\
\hline $\begin{array}{l}\text { Lack of up-to-date } \\
\text { data on the income } \\
\text { Group }\end{array}$ & $5 \%$ & $9 \%$ & $18 \%$ & $9 \%$ & $59 \%$ & 100 \\
\hline $\begin{array}{l}\text { Lack of fund } \\
\text { Lack of collateral }\end{array}$ & $7 \%$ & $9 \%$ & $14 \%$ & $18 \%$ & $59 \%$ & 100 \\
\hline Unemployment & $5 \%$ & $5 \%$ & $9 \%$ & $36 \%$ & $45 \%$ & 100 \\
\hline $\begin{array}{l}\text { Ineffective legal \& } \\
\text { regulatory } \\
\text { Framework }\end{array}$ & $14 \%$ & $18 \%$ & $16 \%$ & $18 \%$ & $34 \%$ & 100 \\
\hline $\begin{array}{l}\text { Land Tenure } \\
\text { System }\end{array}$ & $0 \%$ & $5 \%$ & $9 \%$ & $45 \%$ & $41 \%$ & 100 \\
\hline $\begin{array}{l}\text { Lack } \\
\text { Stakeholders } \\
\text { Involvement }\end{array}$ & $7 \%$ & $2 \%$ & $32 \%$ & $32 \%$ & $27 \%$ & 100 \\
\hline Difficult Terrain & $9 \%$ & $23 \%$ & $11 \%$ & $18 \%$ & $39 \%$ & 100 \\
\hline
\end{tabular}

On population growth, $9 \%$ of respondents answered very low, $2 \%$ low, $14 \%$ moderate, $41 \%$ high and $34 \%$ very high. Cultural diversity as a challenge to low income housing was very high represented by $43 \%, 11 \%$ high, $25 \%$ moderate, $12 \%$ low and $9 \%$ very low. Lack of data on income group was also seen to be very high with 59\%. Lack of fund has the same percentage with lack of data showing high rate of lack of funds as 59\%. Lack of collateral also was high at $50 \%$. Unemployment taking $45 \%$ as very high. Land tenure system has $41 \%$ as very high. $34 \%$ very high goes for ineffective legal and regulatory framework. For lack of stakeholder's involvement, moderate has the highest frequency with $32 \%$ followed by very high at $27 \%$. Finally, $39 \%$ went for very high difficult terrain.

Funding is global factor challenging the construction sector as a result of the global financial crisis. In large economy, the private sector is drafted in to meet existing demand in the form of public private partnership and private finance initiative. These are extreme strategies that are yet struggling to gain acceptance paralyzed by effective legal and regulatory policies coupled with weak macro-economic policies. Lack of fund is the most significant factor facing attempts to house the low income group in Nigeria. This factor was ranked first with a mean score of 4.50. Funding at both individual and government sector is in short supply. The low income group are worst affected as they are battling poverty and unemployment. Even the low income in the government 
employment sector, poor living wages is not enough to meet household means. On the government, the challenge of meeting other demanding needs of other sectors of the economy makes the crucial needs to provide appears less important. As a result very limited proportion of the federal budget and even appropriation are allocated to the sector. There are strong needs to needs and appropriate framework to enhance private sector participation.

Land tenure system in Nigeria allocates total land ownership to the government and the natives settlers who have only fiduciary rights. Such lands are subject to taken over by the government without compensation when needs arises except compensation economic trees and may be properties on such land. Affordability of land for individual development id difficult and expensive coupled with crippling bottleneck at the government agency in charge of land matters registration for approval to develop which is different form planning approval. This is can be quit extensive in terms of the amount of time required- 2 years or more in worst scenarios. Housing provision can be improved tremendously where there are parceled of lands allocated to willing developers for housing purposes. Unemployment is pervasive as permeate all strata of the population. From the educated to the technical skilled and the unskilled, the trend is no different. Petty trading survives the populace and this inform why street lives and unwilling to relocate from the urban centre subsists. Unemployment contributes to the provision of housing problem as a significant factor.

The lack of up-to-date data about the low income sector is not available. Besides the insignificant number in government employ who have their data in government archives, the larger community population are not documented. Such relevant data besides population will include: employment level; income level; demographic; saving profile; income sources; and cultural diversities. Most urban centers in Nigeria witness population explosion as a result of rural urban drift. The current on-going militant insurgent in the north forced resident in the northern part of the country to seek relocation down south. Port Harcourt is one of such receiving urban centers. Nigeria population is generally on steady increase with no supply in housing stock to meet demand. Lack of collateral is the next most significant factor militating against housing for the low income group. Most housing is structured with mortgage with extreme strict condition that can hardly be met by the low income group. Securing loan on the hand is difficulty. A low income earner who seeks to acquire a house is often asked to deposit certificate of land ownership to be granted loan for such acquisition.

Non-involvement of stakeholders in planning of low income housing is another factor in the hierarchy of challenges faced in the provision of housing for the low income group. Other factors include: cultural diversity and ethnic factor, difficult terrain and lack of effective regulatory framework respectively.

\section{Barriers to Public Housing Accessibility by the Low Income Group}

Respondents identified corroborated factors as the reasons why the low income earners who are not public servant cannot access public sector houses. Few of these factors are ubiquitous to the ones identified in the literature which tested in the study. These factors include: affordability; location lack of collateral and lack of security of income which can translated as unemployment. Others factors identified by the study are presented in Table 5 . 
Table 5: Barriers to Accessible Public Housing by the Low Income Group

\begin{tabular}{lll}
\hline Barriers & N & Percentile \\
Lack of Income Security & 15 & 35 \\
Not Government Priority & 8 & 18 \\
Lack of Income Sources & 7 & 16 \\
Lack of Collateral & 12 & 27 \\
Low per Capita Income & 16 & 36 \\
Lack of Comprehensive Data & 9 & 21 \\
Lack of Synergy between Government/Public & 5 & 11 \\
High Cost & 17 & 39 \\
High Interest Rate Payment & 21 & 48 \\
. Lack of Awareness and Availability of Know -How & 15 & 35 \\
. Complex Procedure & 17 & 39 \\
. Bias and Favouritism & 15 & 35 \\
. Non-prioritization of the problem by the government & 14 & 32 \\
. Remote Location & 11 & 25 \\
. Lack of workable Mortgage System/Scheme & 7 & 16 \\
. Public Target at Public Servants only & 6 & 14 \\
Illiteracy & 2 & 5 \\
. Corruption & 5 & 11 \\
. Insufficient Provision & 13 & 30 \\
. Neglect by the government & 2 & 5 \\
\hline
\end{tabular}

$\mathbf{N}=$ Number of Respondents

As shown in Table 5, high interest rate payment is the most significant factor militating non-public servant populace accessibility to public housing facilities. This is the view of the $48 \%$ of the populace. Complex procedure in structured mortgage condition is the second most significant factor. This is the opinion of $39 \%$ of the study sample. Low per capita income is the third factor in the hierarchy. Lack of income security, lack of awareness and bias and favouritism represent the view of $35 \%$ each of the study sample as the fourth most significant factors. $18 \%$ are of the opinion that the government does not prioritized the interest of the non-public servants in the scheme of things while $16 \%$ attribute the problem lack of any income source (unemployment). Lack of comprehensive data on this stratum of the populace represents the view of $21 \%$ while $11 \%$ believes there is no synergy between the government and the populace. Insufficient provision is the opinion of $30 \%$ of the study sample while $5 \%$ each attribute the problem to corruption ant total neglect by the government.

\section{CONCLUSION}

The primary objective of this study is to examine and assess the effect of government's policy on housing delivery in Nigeria. The study focused on the issues that are involved in the assessment of housing, especially the low income group in Port Harcourt, Nigeria. It can be seen from the above findings that housing provision for the urban poor is entirely the duty of the government. Previous policies aimed at delivery affordable housing especially to the low income class has failed. This is because most of the government policies in Nigeria lacked political will and poor implementation of housing policy/programmes, impartiality in the distribution of the housing stock, wrong location of public housing and funding among others. Greater Port Harcourt city swells up daily because of rural-urban migration and thereby creating room for housing deficit in the area. For the government to effectively achieve the vision of the Greater Port Harcourt city towards housing the low income group, they must first of all have the interest of the masses at heart. Government must set up an effective framework for housing delivery that will be supervised by professionals in the built environment and stakeholders in housing provision. Until these policies are well implemented and monitored effectively, housing the low income group will continue to be a mirage. 
It is recommended that to ensure targeted low income earners benefit from the low housing scheme, government should create a viable secondary mortgage market, improve land registration and allocation, carry out compassionate urban renewal, cost saving house designs, provide social housing, fund infrastructural development, site and service schemes and carry out land reform/review of the Land Use Act, grant housing subsidy and also embrace the concept of planning obligations and planning gain which operate in UK.

\section{References}

[1] Adediji, Y. M. D. (2006). Affordable and Functional Housing in a Developing Economy: A case study of Nigeria. Journal of Land Use and Development Studies, Vol. 2 (1), 113-120.

[2] Adejumo, A. A. (2008). Some Thoughts on Affordable and Social Housing in Nigeria.

Available online at http://www.nigeriavillagesquare.com/articles/akintokunbo-aadejumo/some-thoughts-on-affordable-andsocial-housing-in-nigeria.html 10 March, 2013.

[3] Agbola, T. (1998). The Housing of Nigeria: a review of policy Development and implementation. Research report, 14, Ibadan, Development Policy Centre.

[4] Alao, T. (2009). LCCI, Stakeholders explore options for fixing housing shortage. Conference paper.

[5] Aribigbola, A. (2008). Housing Policy Formation in Developing Countries: Evidence of Programme implementation from Akure, Ondo State, Nigeria. Journal of Human Ecology, Vol. 23(2), 125-134.

[6] Aribigbola, A. (2011). Planning and Urban Governance in Developing Societies: The Example of Akure, Ondo State of Nigeria. Journal of Canadian Social Science, Vol. 7(6), 119 $-127$.

[7] Eyare, O. C. (2012). The Effect of Government's Policy on Housing Delivering System in Cross Rivers State. (Unpublished B.Sc Dissertation), Department of Estate Management, Cross Rivers State University of Technology, Calabar, Nigeria.

[8] Federal Executive Council. (2012). Housing, Urban Policy. Available online at http://www.nigeriafirst.org/article_11895.shtml 19 March, 2013

[9] Federal Government of Nigeria. (2004). National Housing Policy. Federal Ministry of Works and Housing, Abuja.

[10] Jiboye, A. D. (2011). Urbanization Challenges and Housing Delivery in Nigeria: The need for an effective policy framework for sustainable development. International Review of Social Sciences and Humanities, Vol. 2(1), 176-185.

[11] Kabir, B., and Bustani, S. A. (2006). A Review of Housing Delivery Efforts in Nigeria.Department of Building, Faculty of Environmental Design, Ahmadu Bello University-Zaria-Nigeria Available

online at http://www.gla.ac.uk/media/media_129767_en.pdf 17 April, 2013

[12] Mabogunje, A. (2002). Housing Delivery Problems in Nigeria. The punch newspaper. Wednesday, May 2002.

[13] Monk, S., Burgess, G., and Whitehead, C. (2010). How can the Planning System Deliver More Housing? Solutions Lessons for Policy and Practice. Available online at http://www.jrf.org.uk/sites/files/jrf/planning-and-housing-delivery-summary.pdf accessed on $25 / 03 / 2013$

[14] Nubi, O. T. (2000). Housing finance in Nigeria. Needs for Re-engineering. Ideal Habitat Cooperative Housing Initiative.. Available online at http://www.housingfinance.org>uploads>Africa 25 March, 2013. 
[15] Nubi, O. T. (2008). Affordable Housing Delivery in Nigeria. Paper presented at the South African Foundation, International Conference and Exhibition. Cape Town.

[16] Olayiwola, L. M., Adeleye, O., and Ogunshakin, L. (2005). Public Housing Delivery in Nigeria: Problems and challenges. Paper presented at World Congress on Housing in Pretoria, South Africa Available online at http://repository.up.ac.za/bitstream/handle/2263/10438/Public\%20Housing\%20Delivery\%20I n\%20Nigeria\%20Pr..?sequence=1 20 March, 2013.

[17] Onibokun, R. (1998). Urban Housing in Nigeria. Ibadan: NISER Publishing.

[18] Onyike, J. A. (2009). Addressing the urban Housing problems of Nigeria in the 21st century. Department of Estate Management. Imo state University Owerri Nigeria.

[19] Peterside, C. S. (2001). Policy Foundation for Affordable Housing in Nigeria. Role of the Secondary Mortgage Market. Available online at www.nigeriaworld.com 23 March, 2013. 